Available online at: http://journals.rsfpress.com/index.php/ijmesh

International Journal of Management, Entrepreneurship, Social Science and Humanities (IJMESH)

ISSN 2580-0981 (online)

Volume 3 Number 2 (2020): 50-67

\title{
Influencer Marketing in Digital Era: Does It Really Works?
}

\author{
Daniel Hermawan \\ Parahyangan Catholic University, Indonesia
}

\begin{abstract}
The increasing number of social media users creates new opportunities in the marketing world. Marketing, which initially focused on the product (product-oriented), now has to be transformed into consumeroriented marketing with many information channels owned by consumers. Consumers are becoming more critical of the products/services offered by companies with the many choices they have. The existence of influencers is a bridge or communication medium that connects companies with consumers in the digital era. Through personality, authenticity, and honesty given by influencers, consumers are expected to be more attached and aware of the existence of a brand. Not infrequently, companies take advantage of influencers in product/service marketing programs in introducing a brand. Influencers become digital advocates who represent brands through endorsement programs. This research wil discuss (1) the phenomenon of influencer marketing in the digital era, (2) the types of influencers and the characteristics of consumers who follow them, (3) the use of influencers in marketing activities in the digital era, in purpose to probe deeper the advantages to employ influencers power from the previous studies. Research use qualitative methods through Pentad analysis to investigate the interconnected concepts about human action and further to find motivation behind various human actions. The study found that influencer marketing can be an effective marketing method by leveraging the influencer's charisma, personality, attitude, and lifestyle in representing the brand. Through personality, authenticity, and honesty given by influencers, consumers are more attached and aware of the existence of a brand.
\end{abstract}

Keywords: influencer marketing, digital era, customer-oriented, information, customer engagement

This is an open access article under the CC-BY-NC license

\section{INTRODUCTION}

Social media has now become part of the lifestyle of modern society. Based on a survey conducted by GlobalWebIndex, the time allocated by each person to access social media increased from 90 minutes per day in 2012 to 143 minutes in the first quarter of 2019. The majority of people who access social media are from Generation $\mathrm{Z}$ with an age range of 16-24 years. This shows that social media has a big influence in the interaction between social relationships, both in terms of friendship, shopping, transportation, political perspectives, to the world of business (Duarte, 2019).

It is not surprising that Facebook, Twitter, YouTube, Instagram, and various other social media are used by businesses in introducing products or services to consumers. Marketing is no longer focused on conventional media, such as newspapers, brochures, posters, TV, radio, and so on, but instead has switched to digital platforms, such as social media to reach more potential consumers. One form of digital marketing is collaboration with influencers or social media users who have a big influence on their followers (Satrianti, 2018). 
Influencers are chosen by several companies today because of their ability to communicate their brand effectively with a more authentic and personal touch. They can recommend a product or service without being overly exaggerated, thus maintaining the trust of their followers to choose a particular product or service. Influencer marketing is also expected to be able to build brands, namely designing communications so that brands can have unique, positive and strong associations in the minds of customers (Mulyadi, 2017).

Previous research has revealed that the use of influencers is a means to build trust between brands and consumers, where the influencer acts as a third party who bridges communication between the two (Biaudet, 2017). Integrity, an action that aims for goodness, and knowledge are means to build trust between influencers and their followers in communicating brands in the fitness industry sector (Baranow, 2019). Meanwhile, Glucksman revealed that influencer marketing through social media would be successful if influencers are able to show confidence, authenticity and maintain interaction with followers in the process of distributing content (Glucksman, 2017).

To probe deeper about the abovementioned studies, research want to discuss (1) the phenomenon of influencer marketing in the digital era, (2) the types of influencers and the characteristics of consumers who follow them, (3) the use of influencers in marketing activities in the digital era. The study was conducted through Pentad analysis with qualitative methods.

\section{LITERATURE REVIEW}

Influencer Marketing

Influencer marketing is a marketing collaboration method by utilizing networks owned by someone who has a big influence on social media. Influencer marketing is becoming the preferred marketing method for brands today because influencers can build trust and loyalty with their followers. They act as representations or ambassadors for some people and help brands to connect with consumers in an authentic way (Mediakix, 2019).

In 2019, influencer marketing was ranked first in the fastest growing media compared to other marketing channels, at $22 \%$.

Figure 1: Development of Marketing Methods in the Digital Era (Odell, 2019)

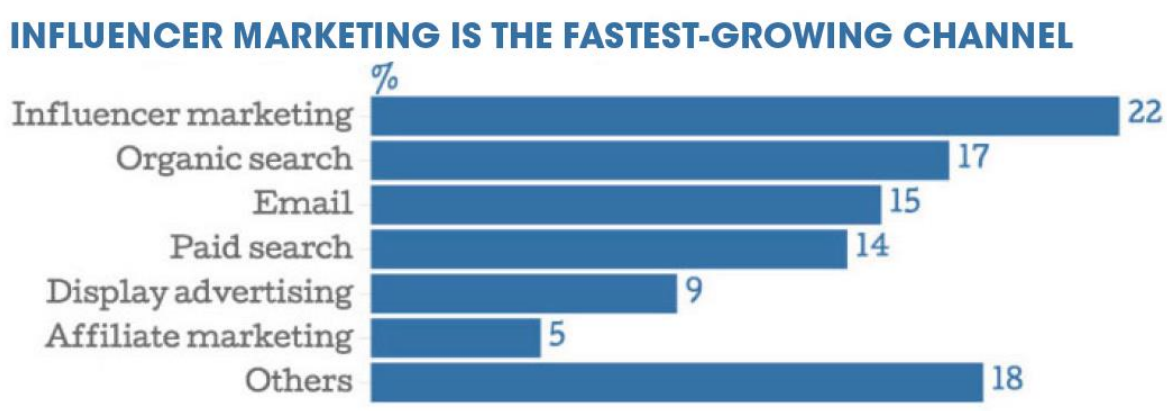

Influencers themselves are divided into two categories, namely micro-influencers and macroinfluencers. Micro-influencers usually have less than 10,000 followers. This type of influencer is suitable for targeting potential consumers who are in certain locations, rather than reaching social media users globally. This influencer's follower type can range from under 10,000 to 100,000 followers. Microinfluencers often have content that is more focused on a specific brand that they personally like. Some 
brands prefer mid-level micro-influencers to macro-influencers because they believe they can be more authentic in their published posts and more accessible. These influencers also have higher engagement rates and can be more cost-effective for brands that will endorse them.

Meanwhile, macro-influencers are usually well-known, known to have broader influence and have social media followers ranging from tens of thousands to millions. This type of influencer is usually hired by the bigger brand names, such as department stores and popular clothing brands. This type of influencer is preferred by brands that already have an established fan base and are looking to increase their visibility and brand awareness (BuzzMG, 2019).

There are 7 reasons why brands like influencer marketing in promoting their products or services, namely (1) a personal touch; (2) society believes in influencers; (3) there is no hidden agenda; (4) influential content than advertising; (5) there is no political element; (6) marketing targets are easier to obtain; (7) cost effectiveness (Odell, 2019).

Instagram

Instagram is the fastest growing social media platform. On this site, users have the ability to post high-resolution photos and can caption images without having a character limit. Apart from posting, users also have the ability to create "Stories" which are uploaded to their profile for a limited time. As many as $71 \%$ of people aged 18-24 years use this social media application (BuzzMG, 2019).

The trend that is developing on Instagram social media today is the increasing use of Instagram Stories. Since March 2018, Instagram Stories usage by Instagram users has increased by $21 \%$. More and more brands are taking advantage of the flexibility of Instagram Stories, which allows them to increase brand visibility at low cost and without spamming their audience. Instagram Stories is also a good strategy for influencers to use in sharing products or services without having to disturb the beauty of their News Feed (Socialbakers, 2019).

The use of sponsored content also continues to increase in various countries with the use of Instagram from year to year. In the Asian region, sponsored content increased by 20\% in February 2019.

Figure 2: Increased Sponsored Content on Instagram (Socialbakers, 2019)

\section{The Rise of Sponsored Content}

(2) Increase of Sponsored Content on Instagram by Region Half Yearly Percent Change in Post Count

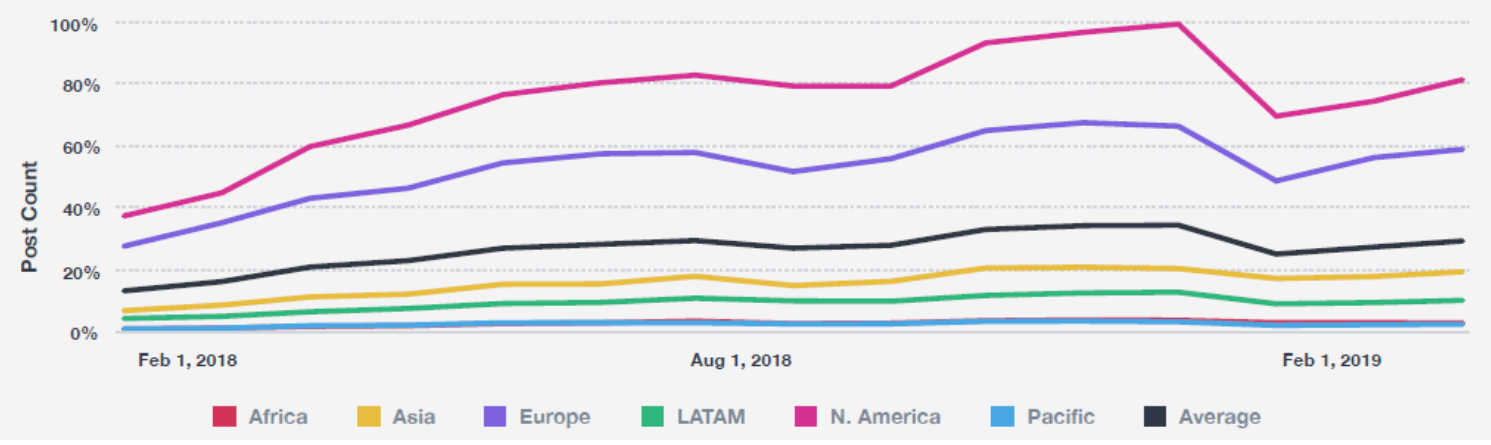

Sponsored content on Instagram is growing across regions. In North America, over the course of 2018 , sponsored content grew by over $150 \%$. 


\section{Brand Awareness}

Brand awareness is the ability of consumers and potential consumers to recognize a brand, product or service. Having a strong brand awareness is the key for a brand to excel in business competition. Psychologically, potential consumers tend to choose products or services from brands they are familiar with and this is what makes sales increase. It is not surprising that increasing brand awareness is a crucial matter that brands must pay attention to in increasing their competitive advantage in the market (Annisa, 2019).

There are 4 levels in brand awareness, namely (1) unaware brand; (2) brand recognition; (3) brand recall; (4) top-of-mind awareness. The unaware brand means that consumers either completely don't know or have never heard of the brand. In brand recognition, new consumers can remember a brand when someone else mentions the brand. Entering the brand recall, consumers can associate a brand with a certain product category. Lastly, consumer top-of-mind awareness remembers the brand as the first to come to mind when talking or being asked about a particular product category (Maulina, 2019).

\section{Previous Research}

Research on influencer marketing has been reviewed in previous studies. In Jantien Wijnen's research entitled "\#InstaFamous: The Effect of Influencer Type and Brand Familiarity on Brand Attitude and Corporate Reputation", influencers have a greater positive influence on brand attitudes than company reputation. In addition, micro-influencers also have a greater influence on brand attitudes than celebrity influencers with a large number of followers (Wijnen, 2019).

Meanwhile, the use of influencer marketing also breaks down the existing barriers between consumers, brands, and followers through content on social media. Influencer marketing changes the way brands interact with consumers with interactive two-way communication (Glucksman, 2017). This is discussed in Morgan Glucksman's research entitled "The Rise of Social Media Influencer Marketing on Lifestyle Branding: A Case Study of Lucie Fink". Influencer marketing replaces interaction patterns that were previously one-way from brands to consumers into interactive marketing patterns through the role of influencers.

Abreu (2019) has also shown that a large proportion of social media users believe that influencers who provide recommendations without gaining financial gain are more trustworthy than influencers who are paid to provide reviews of a brand. Uniquely, consumers don't mind if influencers receive financial incentives from brands to leave brand-related reviews as long as they clearly state it.

\section{RESEARCH METHOD}

Data Collection and Measurement

Research was conducted with Pentad analysis to investigate the interconnected concepts about human action and further to find motivation behind various human actions. In Pentad's analysis, research will analyze five main elements of human dramas: Act, Scene, Agent, Agency, and Purpose. While, The Act refers to what happens, The Scene refers to when and where the action takes place, The Agent refers to the person who takes action, The Agency refers to how the action was actually carried out, and The Purpose refers to why action occurs. Apart from these five elements, Burke also added a sixth element, namely The Attitude to clarify the agent's approach when taking action. By using those elements, research will be able to analyze the use of symbols by humans in communication by identifying ideologies or views in which communicators form messages (Floyd, 2011). 


\section{Validity and Reliability}

The validity and reliability of the study were measured by 4 types of tests, namely data credibility test, transferability test, dependability test, and confirmability test (Sugiyono, 2018). Data credibility test was conducted by conducting a member check with influencers regarding the credibility of the selected influencers purposively using the snowball sampling technique. Transferability tests are carried out by observing and analyzing content regularly to see the consistency of selected influencers in the influencer community in that field. Depenability test is carried out by systematically presenting research data in terms of content and personal branding influencers that can be replicated by other researchers. Confirmability testing is done by observing influencer interactions with followers in each column of content comments made.

\section{FINDINGS}

Based on Pentad analysis, we could understand that: (1). Influencer marketing is a phenomenon in the digital era, (2). Types of consumer's interest is depend on the influencer's characteristics, and (3). Influencers can act as digital advocates for the companies they work with.

1. Influencer marketing is a phenomenon in digital era

Figure 3: Instagram Account @amrazing

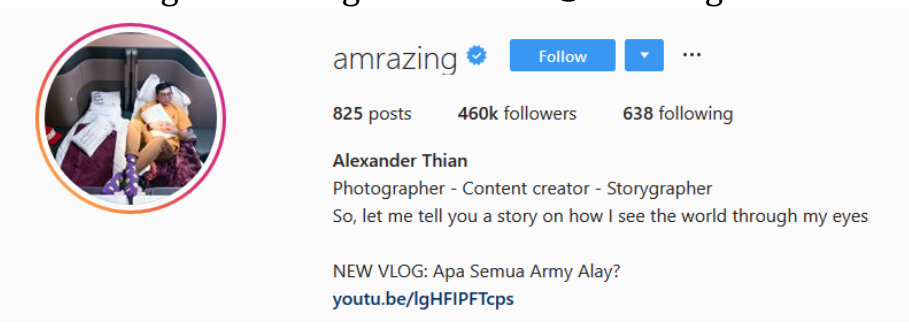

Sample of interest, Alexander Thian, whose Instagram ID was shown on Figure 3 was originally known as a writer who was able to inspire the hearts of readers in his work on blogs. Through the hashtag \#LetMeTellYouAStory, Alexander tells various life stories he has experienced to his followers (Anindya, 2019). His expertise in packaging stories into a touching story has made him favored by followers. Since the emergence of Instagram, he has turned into a photographer who also packs his photographic story into an interesting story. It's no wonder that many brands asking Alexander to be a partner in influencer marketing, given his expertise in packaging a product or service's story to be very personal. 
Figure 4: Sponsored Content in @amrazing account
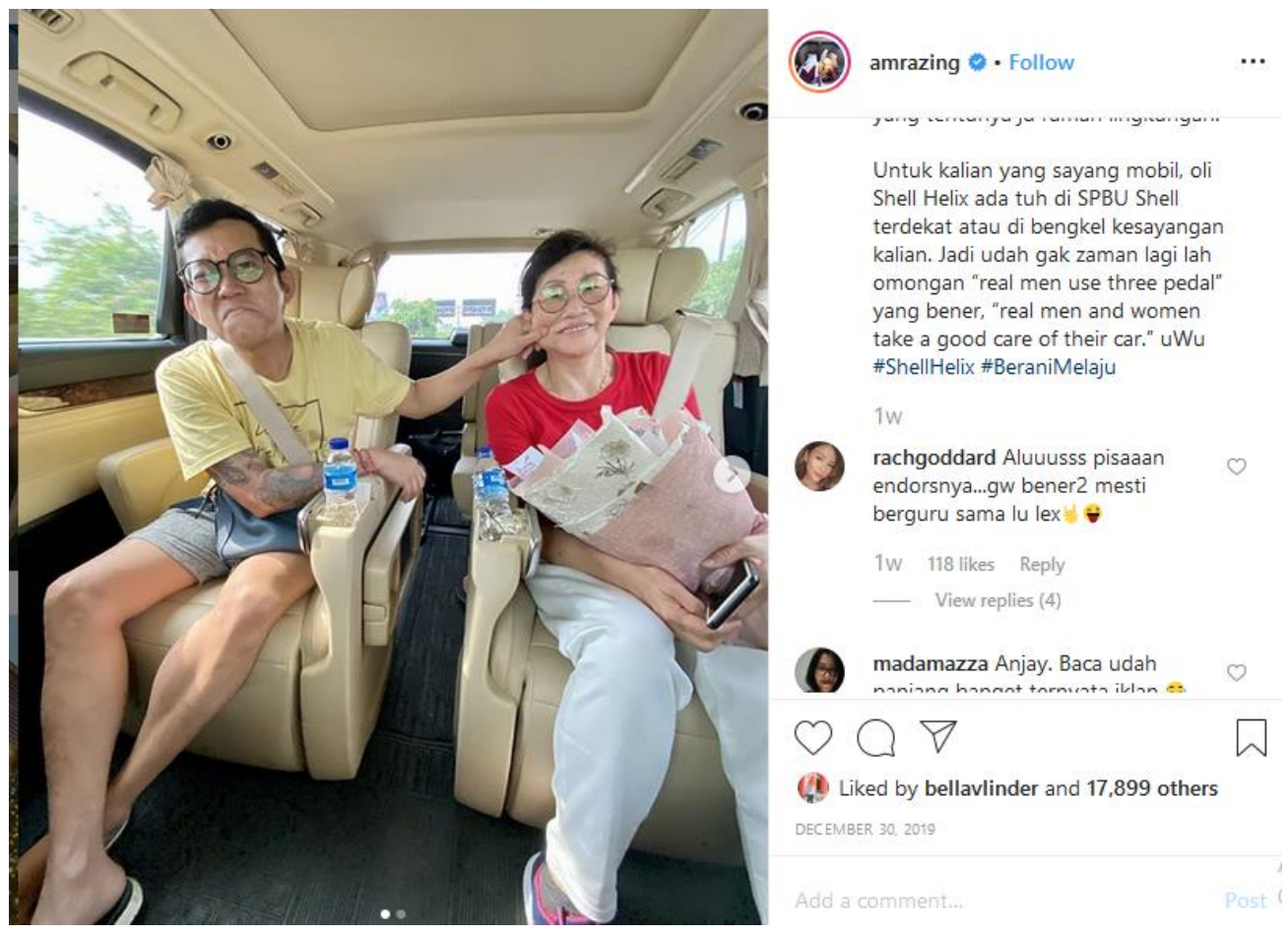

Through the @amrazing post, it can be seen that Alexander's approach is very personal to the product or service being promoted, which raw data we attach on the attachment.

In his post, Alexander Thian tells about the similarities between himself and his mother as the opening story to tell the story of John Blue Mayer, the car that Alexander Thian has used for 6 years. This car is said to use lubricating oil that Alexander Thian is promoting with excellent content and quality, so that the analogy of mother and child love also applies to private vehicles.

Through his posts, it appears that a brand will believe in influencers if they have special skills or abilities that match the brand it represents. 
Figure 5. Paid endorsement in @barrykusuma account

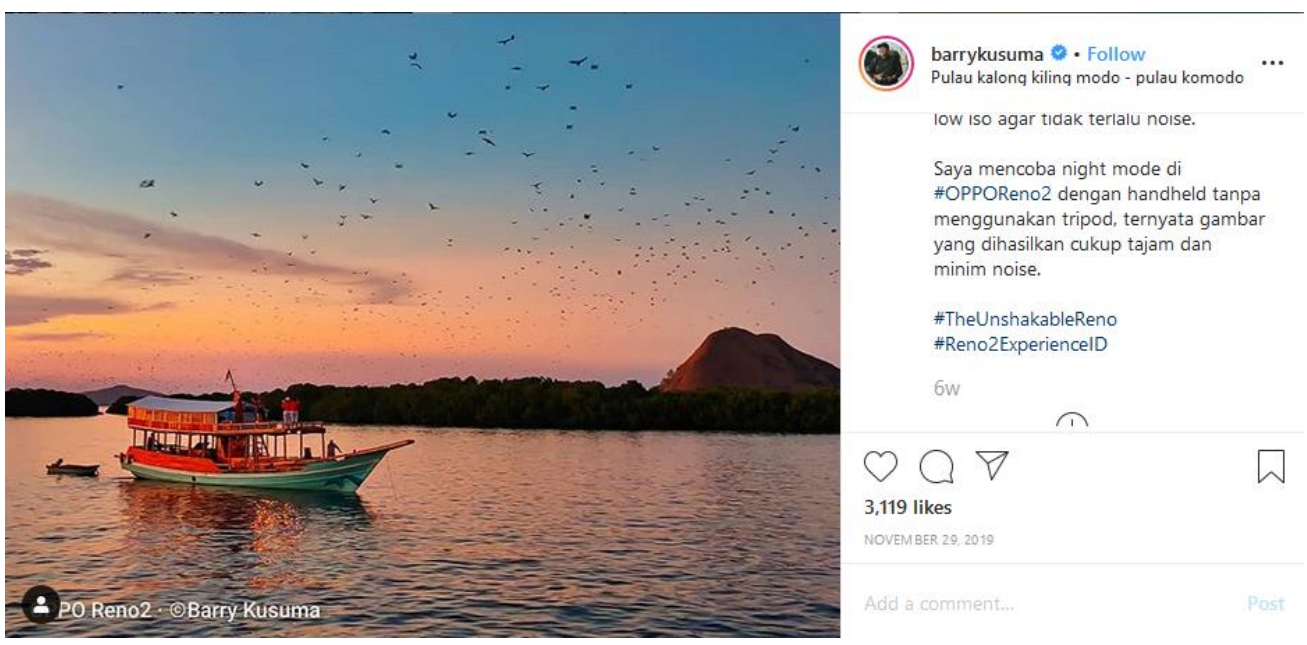

Our other interest, Barry Kusuma is known as the most famous travel photographer in Indonesia. The photos taken by Barry Kusuma in major national media, or even to foreign countries, so it is not surprising that Barry Kusuma is known as an expert in the field of photography (Firmansyah, 2019). The brand that collaborates with Barry Kusuma is also synonymous with Barry's profession as a photographer, in this case the OPPO smartphone brand.

Alexander Thian and Barry Kusuma were chosen as samples because of their expertise and competence in different fields, as well as being able to package content according to their capacities and capabilities. They were selected as samples to describe the influencer marketing phenomenon in the digital age because of their career backgrounds. Their careers did not start as influencers, but as a blog writer (Alexander Thian) and a photographer (Barry Kusuma) who later expanded their career to the world of influencers, so they are considered representative to describe the influencers that grows in the digital era.

The selection of 2 samples in answering this discussion was carried out considering the aspects of competence, background, and suitability of the influencer with the context of the topic being studied, so that it fulfills the expected information elements.

Many large companies invest in influencer marketing because they are considered capable of providing closeness, authenticity, and real expertise with their expertise in processing words, visuals, and content with the personality and personal branding of each influencer.

\section{Types of consumer's interest is depend on the influencer's characteristics}

Influencers themselves consist of various categories that match the interests and personalities of the influencers themselves. For example, influencers in the fields of fashion, travel, culinary, lifestyle, cooking, make-up, and so on. They will be seen as experts by followers who follow their accounts because they share content that matches their followers' interests.

The selection of 2 samples in this study was carried out through strict criteria and considerations, where influencers were judged to have hobbies that match the content they endorsed. In addition, the followers of the selected influencers analyzed reflect the basic characteristics of the influencers 
themselves, so these two samples were selected because they were considered the most suitable for analyzing this topic.

Figure 6: Influencer Marketing Namasuki Bandung by @kokokuliner
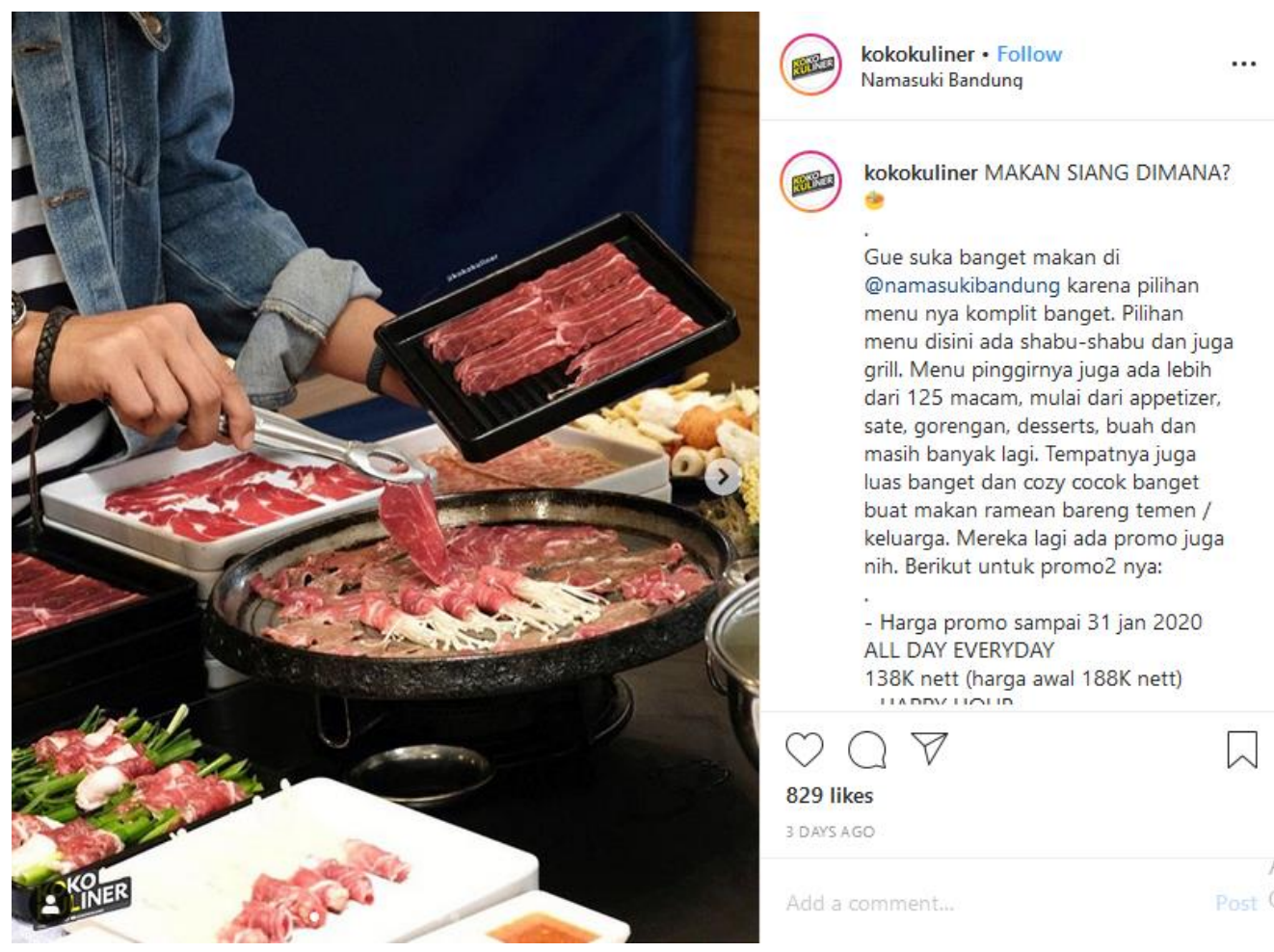

Figure 7: Followers respond relate to @kokokuliner's content

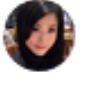

demarinsss Wah dagingnya seger

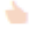

$$
\begin{array}{ll}
2 d \quad \text { Reply } \\
-\quad \text { View replies (1) }
\end{array}
$$

(4) eatingforlyfe ini lebih godaan lagi ko $i s$
2d Reply
- View replies (1)

cicikokokulineran Ikut ko

2d Reply

_ View replies (1) 
For example, the followers of Felix Setiawan @kokokuliner in Figure 6 can be said to be culinary fans seen from the interaction patterns and comments given in Figure 7, in this case the follower provides comments on Instagenically packaged food, as well as the desire to participate in tasting the culinary influencers @kokokuliner.

Figure 8: Paid content in @trinitytraveler account
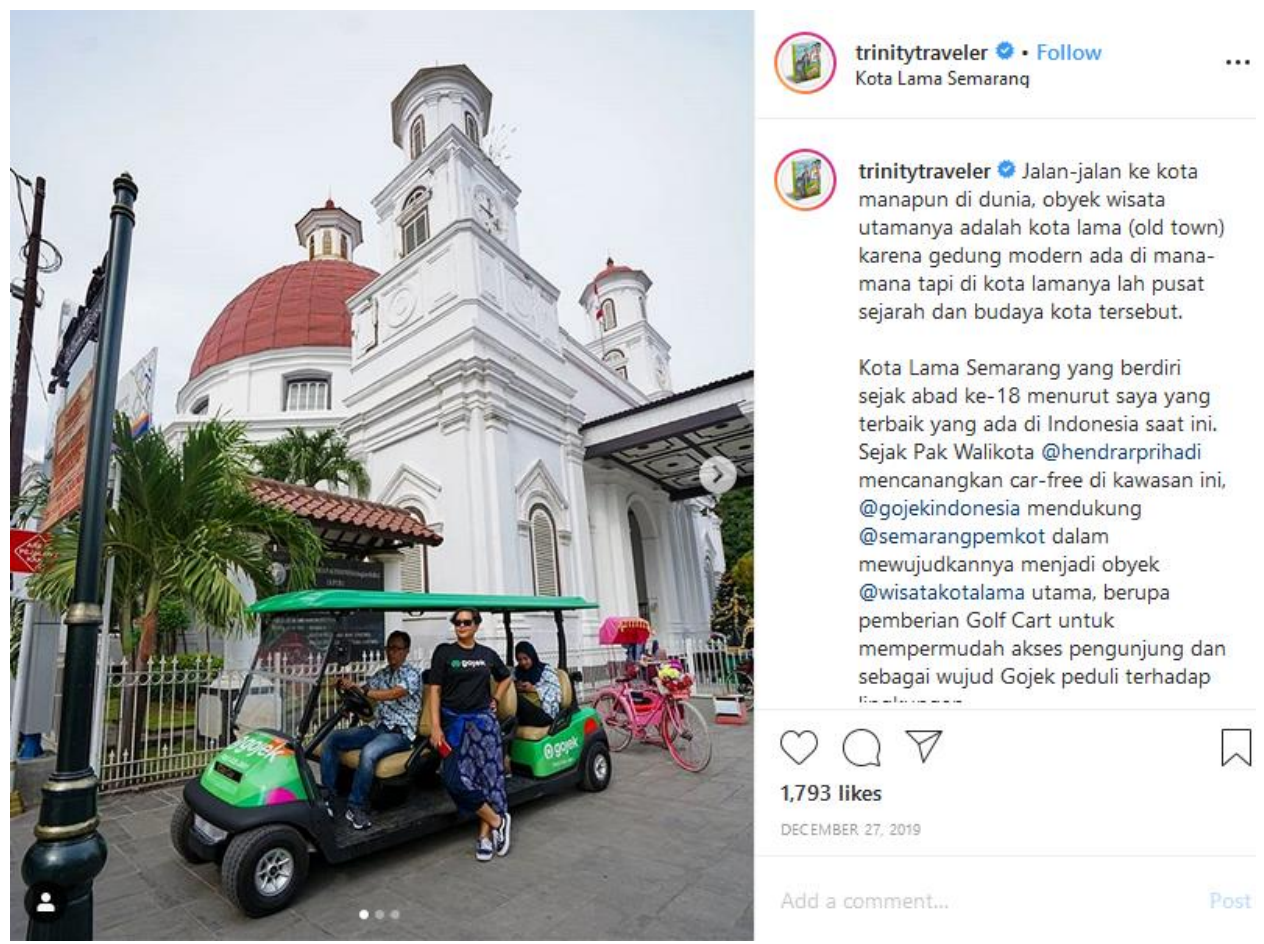

Also, Trinity's Instagram account in Figure 8 is followed by traveling fans. This can be seen from the comments of Trinity followers in Figure 9. 
Figure 9: Comments from followers of @trinitytravel regarding paid content posted

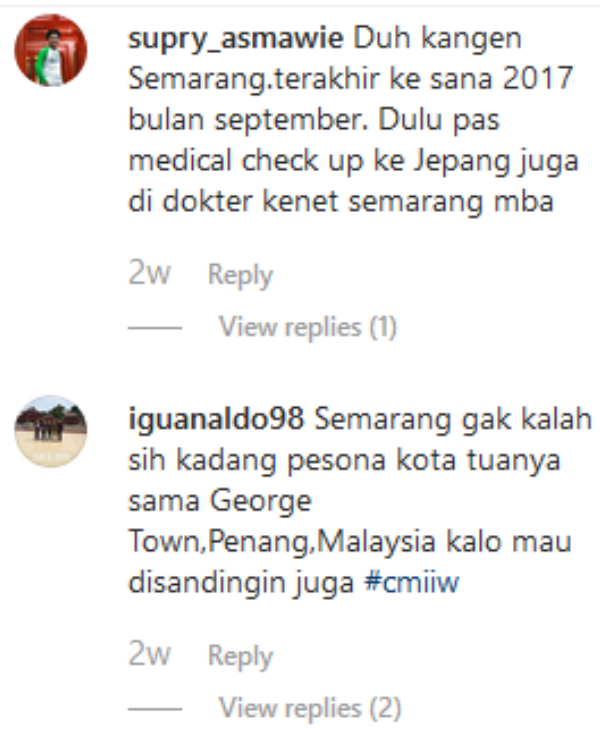

Thus, followers who have the same passion as influencers will interact, even share their own experiences to respond to content posted by influencers.

Felix Setiawan and Trinity Traveler were chosen because they can build a base of followers who have similar hobbies with them authentically. They are also able to package the content they promote without appearing that they are being paid to do this, but instead become part of their life and daily life. Based on the interactions that exist between followers and two influencers who have expertise in the culinary and traveling fields, it can be seen that there is an agglomeration between a person's hobbies and the type of influencer they follow. Influencers become trendsetters who provide a variety of updated information about the development of the world around their fields of interest, thus triggering organic interactions between influencers and their followers.

3. Influencers can act as digital advocates for the companies they work with

Influencers can act as digital advocates for the companies they work with. If a company previously had to work with well-known artists or figures as brand ambassadors, in influencer marketing, influencers will make themselves as representatives of a brand. The personality, attitude, and mindset of influencers will also influence how consumers translate a brand. Therefore, companies must be smart in choosing the right influencer according to the character that they want to create from a brand, considering that the influencer's character will closely attach to the brand image they represent.

The selection of 2 samples in the topic of influencers as digital advocates for companies is based on the involvement and engagement of influencers on contracts from companies to carry out endorsement activities. Given that each influencer has different characteristics, the selection of samples using a purposive technique with certain criteria, especially in this topic, is carried out with several considerations. Influencers who are selected are monitored often endorsement certain brands that are consistent with the personal branding of the influencers. In addition, apart from endorsement activities, they also consistently display their personal image with the content they upload, where both samples meet these criteria. 


\section{Daniel Hermawan}

Figure 10: Paid Partnership @nabilagardena with @cantikcitra
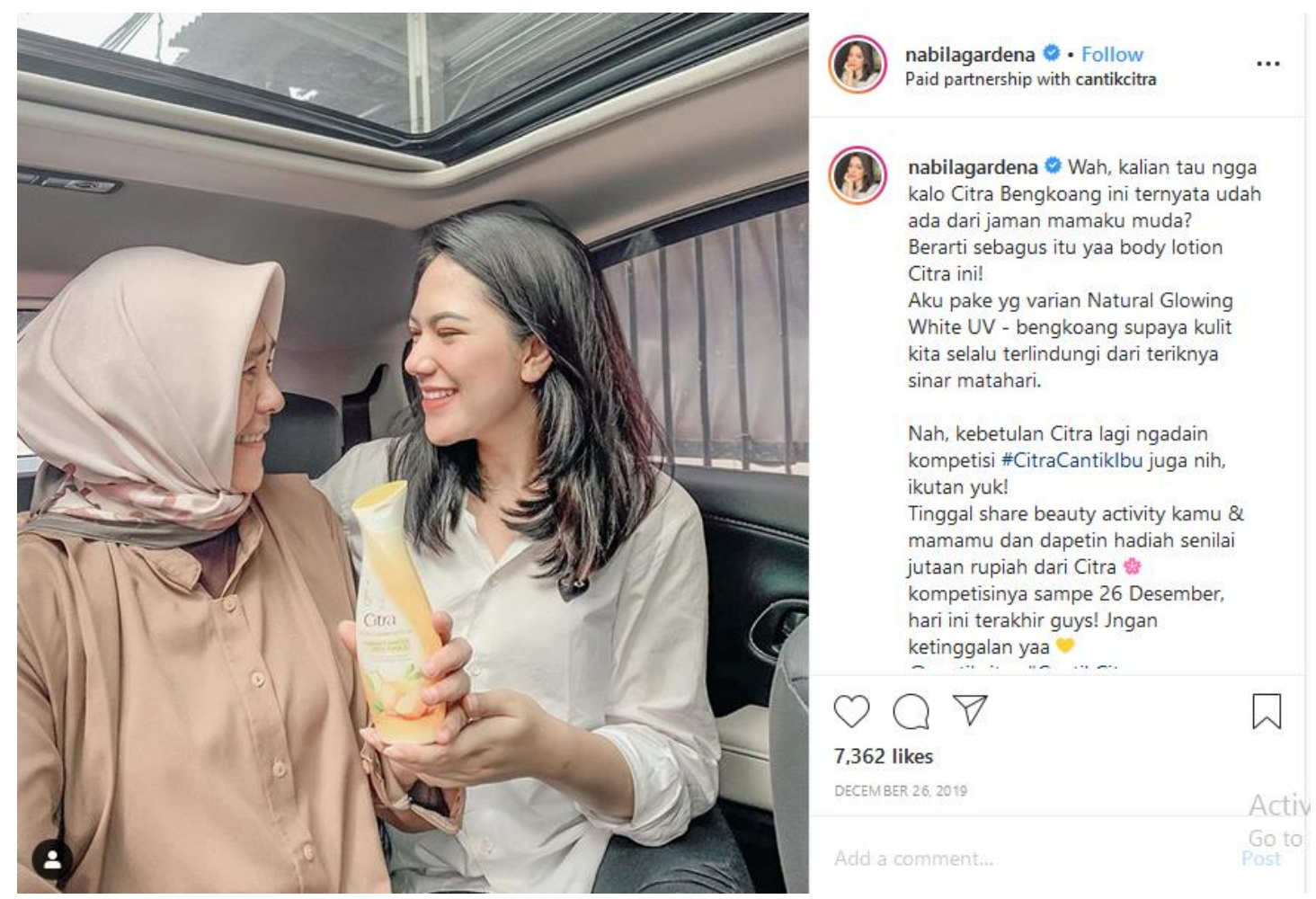

For example, Nabila Gardena Putri, as an influencer who looks stylist, fashionable, and likes makeup, seems to match the brand represented, in this case Citra Bengkoang in Figure 10. This can be seen from one of @nabilagardena's follower responses, namely @istiulous17 in Figure 11 which stated “@jelitavinola dia aja cantik gara2 Citra berarti”, means "she is indeed pretty due to Citra". Thus, the match between endorsed brands and influencer images will strengthen brand awareness in the eyes of consumers. 
Figure 11: Respond followers to paid partnership @nabilagardena

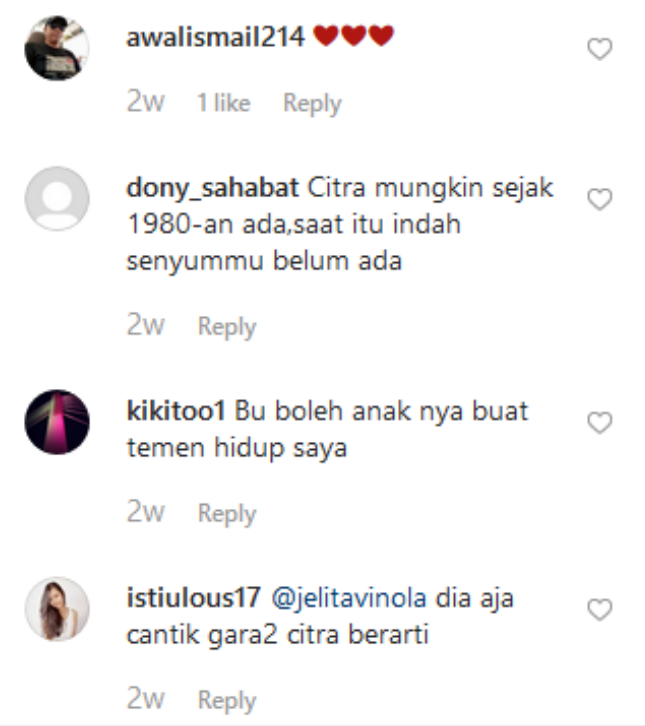

Figure 12: Instagram Stories endorsement @nabilagardena for @nivea_id product

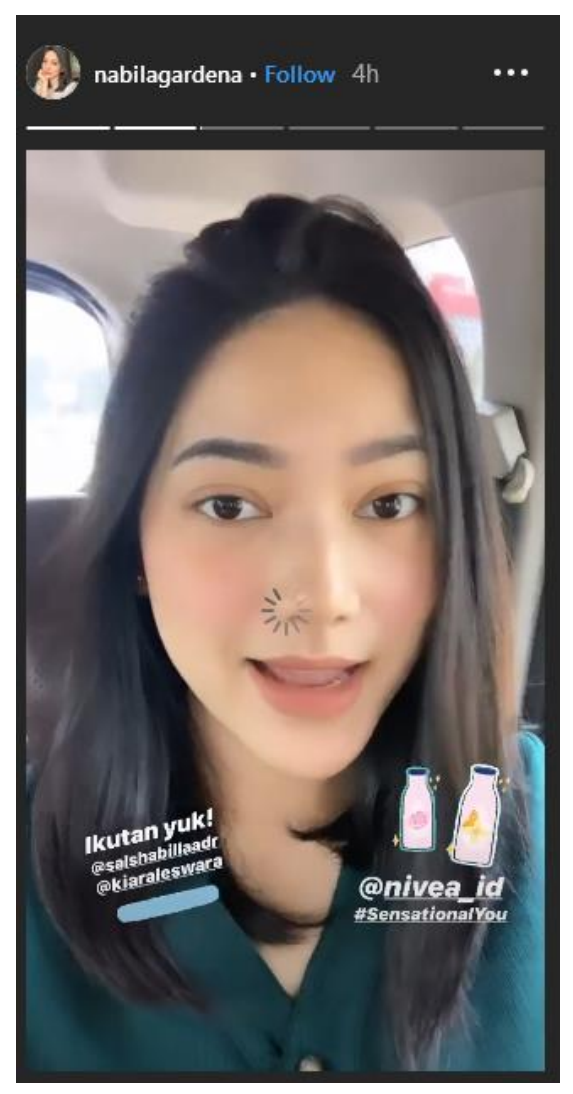


Figure 13: Paid partnership @andirazh with @cantikcitra
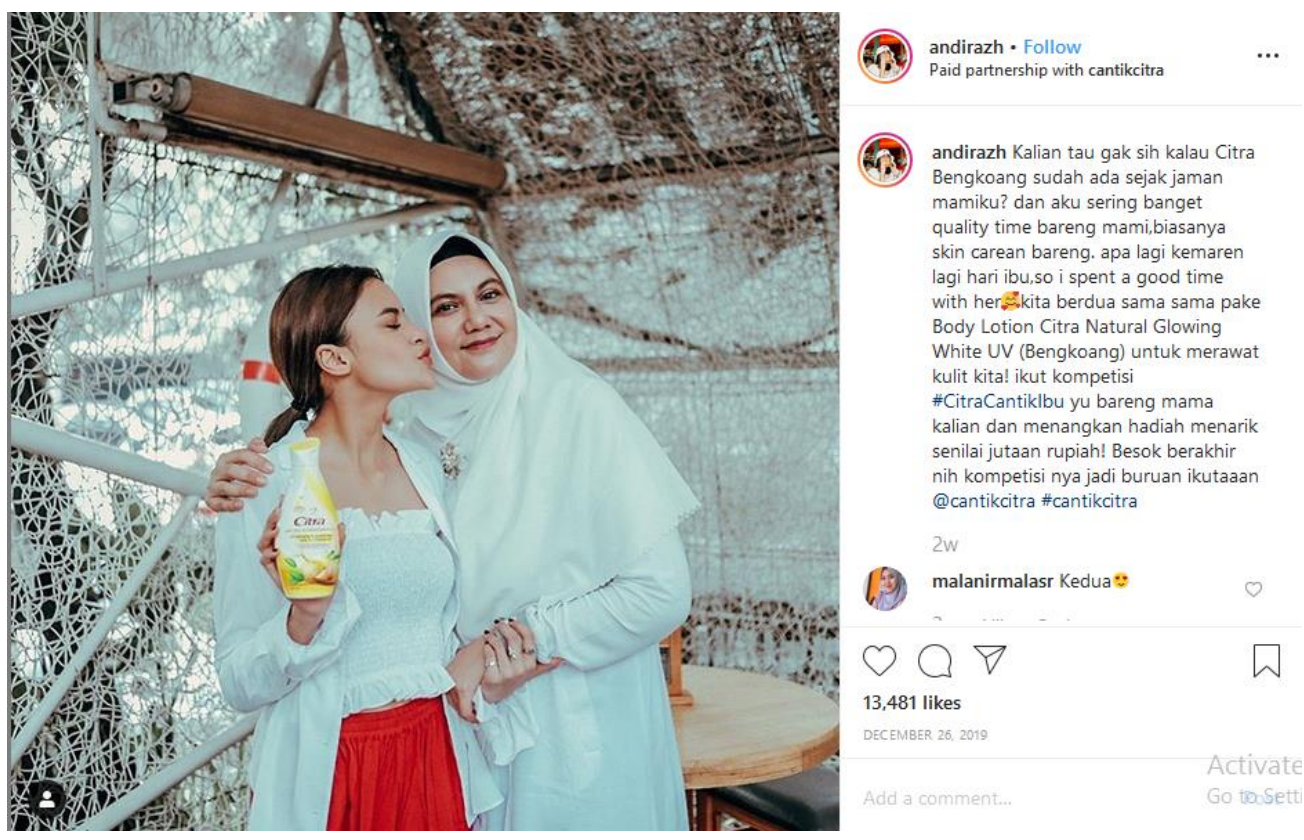

The same thing was seen with the influencer Andira Hadley @andirazh in Figure 13, who collaborated with Citra Bengkoang to promote products and remind the \#CitraCantikIbu competition by taking pictures with her mother while holding Citra Bengkoang products. The match between the character and personal branding of the influencer will also affect how brands place their character in the influencer who promotes it.

Nabila Gardena Putri and Andira Hadley were chosen because both of them are beauty influencers who consistently adopt a trendy lifestyle and become role models for their followers of the same age. They are able to represent the brand as an integral part of their life, so that the paid promotion by the brand does not feel like ordinary advertising. Personal branding owned by influencers can provide positive resonance for companies that have the same character and brand personality, so that the endorsement activities carried out are not impressed as hard selling activities, but soft selling activities that have a more humanist approach to the followers of these influencers.

We could tabulate our finding on Table 1 below in the frame of Pentad Analysis.

Table 1: Pentad Analysis's Description

\begin{tabular}{|c|c|c|c|c|c|c|}
\hline \multirow{2}{*}{$\begin{array}{c}\text { Pentad } \\
\text { Analysis }\end{array}$} & \multicolumn{6}{|c|}{ Influencers } \\
\hline & $\underset{\text { ing }}{\text { @amraz }}$ & $\begin{array}{c}\text { @barrykus } \\
\text { uma }\end{array}$ & $\begin{array}{c}\text { @kokokuli } \\
\text { ner }\end{array}$ & $\begin{array}{c}\text { @trinitytrav } \\
\text { eler }\end{array}$ & $\begin{array}{c}\text { @nabilagar } \\
\text { dena }\end{array}$ & $\begin{array}{c}\text { @andira } \\
\text { zh }\end{array}$ \\
\hline Act & $\begin{array}{l}\text { Expressi } \\
\text { ve } \\
\text { pinching } \\
\text { of the } \\
\text { cheek of }\end{array}$ & $\begin{array}{l}\text { The view of } \\
\text { the boat } \\
\text { with the } \\
\text { gradation of } \\
\text { the sky }\end{array}$ & $\begin{array}{l}\text { The meat is } \\
\text { arranged } \\
\text { neatly for } \\
\text { roasting }\end{array}$ & $\begin{array}{l}\text { Pose with a } \\
\text { golf cart } \\
\text { against the } \\
\text { backdrop of } \\
\text { a beautiful } \\
\text { historical }\end{array}$ & $\begin{array}{l}\text { Mother and } \\
\text { daughter face } \\
\text { each other, } \\
\text { smile, and } \\
\text { hold hands }\end{array}$ & $\begin{array}{l}\text { Shows } \\
\text { the } \\
\text { daughter' } \\
\text { s love for } \\
\text { the } \\
\text { mother }\end{array}$ \\
\hline
\end{tabular}




\begin{tabular}{|c|c|c|c|c|c|c|}
\hline & $\begin{array}{l}\text { the } \\
\text { mother }\end{array}$ & & & $\begin{array}{l}\text { building in } \\
\text { the Old City } \\
\text { of Semarang }\end{array}$ & $\begin{array}{l}\text { with each } \\
\text { other }\end{array}$ & $\begin{array}{l}\text { with a } \\
\text { touch and } \\
\text { a kiss }\end{array}$ \\
\hline Scene & $\begin{array}{l}\text { Sit side } \\
\text { by side in } \\
\text { the } \\
\text { middle } \\
\text { seat of } \\
\text { the car }\end{array}$ & $\begin{array}{l}\text { An ocean } \\
\text { that has a } \\
\text { view of the } \\
\text { hills in } \\
\text { Komodo } \\
\text { Island }\end{array}$ & $\begin{array}{l}\text { A table in } \\
\text { Namasuki } \\
\text { Bandung }\end{array}$ & $\begin{array}{l}\text { The Old City } \\
\text { of Semarang } \\
\text { with } \\
\text { beautiful } \\
\text { historical } \\
\text { building }\end{array}$ & $\begin{array}{l}\text { In the middle } \\
\text { seat of a car } \\
\text { that has an } \\
\text { open roof }\end{array}$ & $\begin{array}{l}\text { A room } \\
\text { with a } \\
\text { white } \\
\text { decorativ } \\
\text { e } \\
\text { backgrou } \\
\text { nd in a } \\
\text { mesh } \\
\text { shape }\end{array}$ \\
\hline Agent & $\begin{array}{l}\text { Mother } \\
\text { and son }\end{array}$ & $\begin{array}{l}\text { The boat is } \\
\text { stopping to } \\
\text { catch fish. }\end{array}$ & $\begin{array}{l}\text { Male hand } \\
\text { in jeans } \\
\text { jacket } \\
\text { outfit }\end{array}$ & $\begin{array}{l}\text { Three } \\
\text { people, } \\
\text { namely } \\
\text { influencers, } \\
\text { golf cart } \\
\text { drivers, and } \\
\text { passengers }\end{array}$ & $\begin{array}{l}\text { Mother and } \\
\text { daughter }\end{array}$ & $\begin{array}{l}\text { Mother } \\
\text { and } \\
\text { daughter }\end{array}$ \\
\hline Agency & $\begin{array}{l}\text { Gives } \\
\text { flowers } \\
\text { and } \\
\text { special } \\
\text { treatmen } \\
\mathrm{t} \text { to the } \\
\text { mother }\end{array}$ & $\begin{array}{l}\text { Composition } \\
\text { of birds, } \\
\text { boats, sky } \\
\text { colors, and } \\
\text { hills } \\
\text { balanced } \\
\text { and } \\
\text { aesthetics }\end{array}$ & $\begin{array}{l}\text { Shows the } \\
\text { abundant } \\
\text { variety of } \\
\text { foods and } \\
\text { cooking } \\
\text { techniques } \\
\text { for these } \\
\text { foods }\end{array}$ & $\begin{array}{l}\text { Shows a } \\
\text { holiday } \\
\text { atmosphere } \\
\text { with casual } \\
\text { clothes }\end{array}$ & $\begin{array}{l}\text { Show the } \\
\text { love } \\
\text { relationship } \\
\text { between } \\
\text { mother and } \\
\text { daughter by } \\
\text { highlighting } \\
\text { Citra } \\
\text { products }\end{array}$ & $\begin{array}{l}\text { Show the } \\
\text { love } \\
\text { relations } \\
\text { hip } \\
\text { between } \\
\text { mother } \\
\text { and } \\
\text { daughter } \\
\text { by } \\
\text { highlighti } \\
\text { ng Citra } \\
\text { products }\end{array}$ \\
\hline Purpose & $\begin{array}{l}\text { Explain } \\
\text { the } \\
\text { harmoni } \\
\text { ous } \\
\text { relations } \\
\text { hip } \\
\text { between } \\
\text { mother } \\
\text { and child } \\
\text { by } \\
\text { inserting } \\
\text { the } \\
\text { advantag } \\
\text { es of } \\
\text { Shell } \\
\text { Helix oil }\end{array}$ & $\begin{array}{l}\text { Demonstrat } \\
\text { e excellence } \\
\text { in } \\
\text { photograph } \\
\text { y and } \\
\text { highlight } \\
\text { OPPO Reno2 } \\
\text { features }\end{array}$ & $\begin{array}{l}\text { Tells about } \\
\text { eating } \\
\text { experience } \\
\text { s with } \\
\text { various } \\
\text { foods that } \\
\text { can be } \\
\text { enjoyed, as } \\
\text { well as } \\
\text { promo } \\
\text { offers }\end{array}$ & $\begin{array}{l}\text { Providing } \\
\text { opinion as a } \\
\text { travel } \\
\text { blogger } \\
\text { about the old } \\
\text { city of } \\
\text { Semarang } \\
\text { and GO-JEK's } \\
\text { contribution } \\
\text { to tourism in } \\
\text { the form of a } \\
\text { golf cart }\end{array}$ & $\begin{array}{l}\text { Promote } \\
\text { Citra } \\
\text { products by } \\
\text { informing } \\
\text { product } \\
\text { history and } \\
\text { prize } \\
\text { competitions } \\
\text { between } \\
\text { mothers and } \\
\text { daughters }\end{array}$ & $\begin{array}{l}\text { Promote } \\
\text { Citra } \\
\text { products } \\
\text { by } \\
\text { informing } \\
\text { product } \\
\text { history } \\
\text { and prize } \\
\text { competiti } \\
\text { ons } \\
\text { between } \\
\text { mothers } \\
\text { and } \\
\text { daughter } \\
\text { s }\end{array}$ \\
\hline $\begin{array}{l}\text { Unique } \\
\text { Selling }\end{array}$ & $\begin{array}{l}\text { Storytelli } \\
\text { ng }\end{array}$ & $\begin{array}{l}\text { Photograph } \\
\text { y Skills }\end{array}$ & $\begin{array}{l}\text { Testimonia } \\
\text { ls }\end{array}$ & $\begin{array}{l}\text { Demonstrate } \\
\text { expertise in }\end{array}$ & $\begin{array}{l}\text { Visual } \\
\text { personal } \\
\text { appeal }\end{array}$ & $\begin{array}{l}\text { Visual } \\
\text { personal } \\
\text { appeal }\end{array}$ \\
\hline
\end{tabular}




\begin{tabular}{|c|l|l|l|l|l|}
\hline $\begin{array}{c}\text { Proposit } \\
\text { ion }\end{array}$ & & & $\begin{array}{l}\text { the world of } \\
\text { travel }\end{array}$ & \\
\hline
\end{tabular}

Table 1 summarizes the three main discussions in this study, where each influencer has a strategic role in representing the brands they endorse in any content they produce. Every influencer has different writing styles, photos, skills, expertise, and characteristics. This makes marketing through influencers a part of marketing activities in the digital era that is effective in attracting public interest, especially the followers of these influencers, to find out about brands with a more personal and humanist approach.

\section{DISCUSSION}

The phenomenon of influencer marketing in the digital era is still a hot trend favored by companies to promote brands, be it in the form of products or services. A large and emotionally close fan base between followers and influencers becomes a profitable market share for companies to introduce products or services to potential customers, especially in industrial sectors that are close to the daily life and lifestyle of influencers.

Of course, as a business actor, a company must have Key Performance Indicators (KPI) that can measure the effectiveness of influencer marketing. This can be seen from the number of reach, social interactions (in the form of likes, shares, comments, follows, mentions), brand mentions, and the increase in traffic from the website. This aims to determine the effectiveness of influencer-generated content on consumer engagement with a brand.

Likewise, the content strategy carried out by influencers must be in accordance with the ultimate goal desired by the company in introducing the brand. In this case, content with an unboxing type, a campaign with a special theme or hashtag, pre-release of the product to be launched, storytelling from a particular story, giveaways or a contest with product or service prizes, to discount codes. The right content approach will support how companies can maximize influencer marketing to introduce the products or services offered effectively. This also increases brand awareness of the brand being promoted.

\section{THEORITICAL AND PRACTICAL IMPLICATION}

Influencer marketing is a choice of digital marketing methods that are popular in reaching Generation Z who are in the 18-24 age range and use Instagram media. Theoretically, influencer marketing will increase consumer brand awareness of the brand being promoted, whether consumers see directly through the influencer's News Feed or indirectly through Instagram Stories. The interaction of followers with influencers when providing reviews about products or services indirectly exposes followers to potential consumers of the brand.

Practically, the effectiveness of influencer marketing promotional activities is still a question, whether it is limited to brand recognition or up to the call for action stage for consumers. If influencer marketing is limited to brand recognition, then it should also be noted the validity of the interactions carried out by the followers of the influencer concerned. Are the likes, shares, and comments indicators made by followers of organic interactions or fake engagement. This needs to be a concern for companies that will use influencer marketing as their marketing method, especially for macro-influencers with a large number of followers. 


\section{CONCLUSION}

Influencer marketing can be said to be an innovative marketing method in the digital era by utilizing the influencer's charisma, personality, attitude, and lifestyle in representing the brand to be promoted. Influencers' expertise and expertise in creating content can make followers bond emotionally which hopefully also affects how followers perceive the brand being promoted. The use of influencer marketing itself must be adjusted to who is the target market, budget, expected Key Performance Indicators, and suitability between influencers and brands. Through the right approach, influencer marketing can become an effective marketing strategy in the digital era.

\section{LIMITATION \& FURTHER RESEARCH}

This study has several limitations, especially from the consumer perspective. This study does not provide room for followers, in this case potential consumers in telling and assessing their experiences when viewing content posted by influencers they follow in assessing the effectiveness of the program, both in terms of brand awareness and purchasing decisions. In addition, the influencers studied in this study are influencers who live in Indonesia, so it cannot be generalized to identify influencer marketing for influencers abroad. In addition, this study has not discussed the strategic aspects of corporate marketing through influencer marketing through the interview, so we cannot know for sure the ultimate goal expected of influencer marketing by companies. This study can be a further research conducted to enrich research on influencer marketing.

\section{REFERENCES}

Abreu, R. (2019). Marketing and purchasing intention of Millenials: the role of Perceived Authenticity and Trust. Dublin: Dublin Business School.

Anindya, S. (2019, Maret 8). 10 Fakta Alexander Thian 'amrazing', Travel Blogger yang Menginspirasi. Retrieved from IDN Times: https://www.idntimes.com/hype/entertainment/shafira-anindya-n/10-fakta-alexanderthian-amrazing-travel-blogger-yang-menginspirasi-c1c2

Annisa, T. (2019, Mei 15). Pentingnya brand awareness dan 5 cara meningkatkannya. Retrieved from PT EKRUT TEKNOLOGI PASIFIK: https://www.ekrut.com/media/brand-awarenessadalah

Baranow, R. (2019). The Impact of Influencer Marketing in The Fitness Industry on Consumers' Trust. Vienna: Modul Vienna University.

Biaudet, S. (2017). Influencer Marketing as a Marketing Tool. Helsinki: Yrkeshögskolan Arcada.

BuzzMG. (2019). Influencer 101 Handbook. Haddonfield: BuzzMG.

Duarte, F. (2019, September 9). Berapa banyak waktu yang dihabiskan rakyat Indonesia di media sosial? Retrieved from BBC: https://www.bbc.com/indonesia/majalah-49630216

Firmansyah, N. (2019, Mei 21). Top 10 Fotografer di Indonesia. Retrieved from StarNgage: https://starngage.com/top-10-fotografer-di-indonesia/

Floyd, K. (2011). Interpersonal communication. New York: McGraw-Hill.

Glucksman, M. (2017). The Rise of Social Media Influencer Marketing on Lifestyle Branding: A Case Study of Lucie Fink. Elon Journal of Undergraduate Research in Communications, Vol. 8, No. $2,77-87$. 
Maulina, R. (2019, Agustus 30). Membangun Brand Awareness untuk Kelangsungan Bisnis. Retrieved from Jurnal: https://www.jurnal.id/id/blog/membangun-brand-awarenessuntuk-kelangsungan-bisnis/

Mediakix. (2019). The CMO's Guide to Influencer Marketing. Santa Monica: Mediakix.

Mulyadi, I. (2017, April 28). Customer Oriented Strategy. Retrieved from Marketing.co.id: https://marketing.co.id/customer-oriented-strategy/

Odell, P. (2019). The Power of Influencers. Norwalk: Chief Marketer.

Satrianti, P. A. (2018, Februari 8). 8 Tren Digital Marketing di Tahun 2018 yang Perlu Kamu Ketahui. Retrieved from Tech in Asia: https://id.techinasia.com/8-tren-digital-marketing-tahun2018

Socialbakers. (2019). Must-Know Influencer Marketing Trends Q1 2019. Prague: Socialbakers.

Sugiyono. (2018). Metode Penelitian Kualitatif. Bandung: Alfabeta.

Wijnen, J. (2019). \#InstaFamous: The Effect of Influencer Type and Brand Familiairity on Brand attitude and Corporate Reputation. Enschede: University of Twente.

\section{ATTACHMENT}

The caption that accompanies the photo of Alexander Thian through his Instagram @amrazing:

"Setelah semingguan traveling bareng nyokap, aku baru ngeh beberapa sifatku mirip banget sama beliau: - suka fotoin apa aja

- kalau jalan cepat banget () (ini sering banget diprotes sama orang-orang)

- sering memisahkan diri dari rombongan karena mau motret...

- dan gak pake bilang-bilang karena mikir "oh i know where they are jadi gosahlah bilang lagian cuma sebentar"

- dan ujung-ujungnya dicariin. In this case, aku yang sering nyariin mama karena beliau suka mendadak ngilang. Apalagi pas di champs ellysees ya allah penuh manusia doi mendadak ngilang bikin jantungan sebel banget deh. (Terus sahabatku bilang: YA ELO JUGA SAMA PERCIS!)

- suka excited sama every little things because every little things are exciting for her (and for me)

- jalan kaki dari pagi sampe malem gak ada capeknya apalagi kalau pemandangan bagus.

- we prefer nature over city view.

- kalo nyeletuk suka out of the box (i think it's my aquarian quality but appently I got it from my mum wkwk)

Jadi idiom like mother like son ternyata bener ya, wakkk.

Sebelum berangkat, mama sempat nanya: mana mobil kamu? Pas aku bilang lagi masuk ke bengkel untuk diservis, dia bilang gini, "kirain dijual buat jalan-jalan.” Untung aku gak cerita kalau itu mobil abis ditabrak. Bisa tambah panjang omelannya.

Btw, 6 tahun punya mobil, gak pernah mobilku rewel. Aside from the penyok ditabrak si John Blue Mayer (iya, mobilku aku kasih nama) baik banget, nggak pernah mogok, gak pernah ada masalah sama sekali. Salah satu alasannya, rutin servis di bengkel dan pake pelumas Shell Helix Ultra yang punya teknologi Pure Plus yg artinya dibuat $99.9 \%$ dari gas alam yang murni, ngebuat performa mesin oke terus, dan juga kekentalan OW nya membuat konsumsi BBM makin efisien yang tentunya jd ramah lingkungan. 
Untuk kalian yang sayang mobil, oli Shell Helix ada tuh di SPBU Shell terdekat atau di bengkel kesayangan kalian. Jadi udah gak zaman lagi lah omongan "real men use three pedal" yang bener, "real men and women take a good care of their car." uWu

\#ShellHelix \#BeraniMelaju" 